\title{
Treatment with G-CSF reduces acute myeloid leukemia blast viability in the presence of bone marrow stroma
}

\author{
Meritxell Nomdedeu,2, María Carmen Lara-Castillo', Amaia Etxabe', Josep María Cornet-Masana', \\ Marta Pratcorona ${ }^{1,2,3,5}$, Marina Díaz-Beyá ${ }^{1,2,3}$, Xavier Calvo ${ }^{4}$, María Rozman ${ }^{4}$, Dolors Costa ${ }^{4}$, Jordi Esteve $e^{1,2,3}$ \\ and Ruth M. Risueño ${ }^{1 *}$ (B)
}

\begin{abstract}
Background: The resulting clinical impact of the combined use of G-CSF with chemotherapy as a chemosensitizing strategy for treatment of acute myeloid leukemia (AML) patients is still controversial. In this study, the effect of ex vivo treatment with G-CSF on AML primary blasts was studied.

Methods: Peripheral blood mononuclear cells from AML patients were treated with G-CSF at increasing doses, alone or in co-culture with HS-5 stromal cells. Cell viability and surface phenotype was determined by flow cytometry $72 \mathrm{~h}$ after treatment. For clonogenicity assays, AML primary samples were treated for $18 \mathrm{~h}$ with G-CSF at increasing concentrations and cultured in methyl-cellulose for 14 days. Colonies were counted based on cellularity and morphology criteria.

Results: The presence of G-CSF reduced the overall viability of AML cells co-cultured with bone marrow stroma; whereas, in absence of stroma, a negligible effect was observed. Moreover, clonogenic capacity of AML cells was significantly reduced upon treatment with G-CSF. Interestingly, reduction in the AML clonogenic capacity correlated with the sensitivity to chemotherapy observed in vivo.

Conclusions: These ex vivo results would provide a biological basis to data available from studies showing a clinical benefit with the use of G-CSF as a priming agent in patients with a chemosensitive AML and would support implementation of further studies exploring new strategies of chemotherapy priming in AML.
\end{abstract}

Keywords: G-CSF, AML, Chemotherapy priming

\section{Background}

According to the hierarchic model of cancer, AML cells are maintained by a subset of cells, called leukemic stem cells (LSCs), which have the capacity of self-renewal and differentiation [1]. Due to their stem cell-like properties, LSCs are the cell population showing a highest resistance to conventional chemotherapeutic agents used in AML treatment, such as anthracyclines and cytarabine [2]. Additionally, chemotherapy resistance may be

\footnotetext{
*Correspondence: risueno@carrerasresearch.org

1 Josep Carreras Leukaemia Research Institute, Campus Clínic-University

of Barcelona, Rosselló 149-153, 08036 Barcelona, Spain

Full list of author information is available at the end of the article
}

partially explained by the protective effect exerted by bone marrow niche on leukemia cells against virtually any type of therapy [3], and might contribute to the high incidence of relapse observed after frontline chemotherapy [2]. Therefore, AML therapy requires the complete eradication of LSCs in order to achieve long-term cure. Administration of granulocyte colony-stimulating factor (G-CSF) concurrently with induction chemotherapy, as a priming strategy, has been used based on pre-clinical data suggesting a sensitization of LSCs to the cytotoxic effect of conventional chemotherapy with the concomitant administration of G-CSF via differentiation induction, cell cycle entry stimulation, and mobilization from 
the bone marrow [4]. Additionally, G-CSF could exert its anti-leukemic effect inducing mobilization out of the protective bone marrow microenvironment by disrupting the CXCR4-CXCL12 axis [5].

In clinics, the simultaneous administration of G-CSF and chemotherapy as a priming strategy has yielded conflicting results. Thus, some reports have described a favorable effect of G-CSF priming in favorable and the intermediate risk AML patients, without clinical benefit in patients with unfavorable cytogenetics [6,7]. In contrast, other studies have failed to show a clinical effect of priming strategies, although these conflicting results must be due in part to different patient inclusion criteria, disease status and treatment administered $[8,9]$.

G-CSF is the main cytokine that drives granulopoiesis exerting its function through the G-CSF receptor (G-CSFR). G-CSFR is a single transmembrane receptor that belongs to the cytokine receptor type I superfamily [10]. The intracellular region lacks intrinsic tyrosine kinase activity, but contains two conserved membraneproximal motifs: box 1 and box 2, involved in Jak kinase activation. In the membrane-distal intracellular tail, there is a more distal box 3 motif and specific tyrosine residues important for signaling transduction [11]. Upon ligand recognition, G-CSFR homodimerizes allowing trans-phosphorylation and activation of Jak2 kinases that are constantly bound to box 1 and 2, which consequently initiates downstream intracellular signaling cascades, including Jak/STAT/Socs, Ras/Raf/Erk and PI3K/ Akt pathways. As a result, transcription changes that impact on survival, migration, proliferation and differentiation are induced [12]. G-CSF/G-CSFR axis regulates myelopoiesis under basal conditions of hematopoiesis and neutrophil production during emergency granulopoiesis [4]. G-CSF signaling is implicated in hematopoietic stem/progenitor cell mobilization through three different mechanisms G-CSFR-independent: induction of proteases, attenuation of function of adhesion molecules, and disruption of signaling initiated by CXCL12 (SDF-1) through CXCR4 [13]. G-CSF also promotes mobilization of mature myeloid cells via induction of the transcriptional repressor GFI-1, which attenuates their responsibleness to bone marrow CXCL12 [14].

Here, we analyzed the ex vivo effect of G-CSF on primary AML samples in order to elucidate the biological mechanisms underlying chemotherapy priming strategies with this agent [15-18]. Our results suggest that the anti-leukemic effect of G-CSF treatment is mostly stroma-dependent. Moreover, cell viability and clonogenic capacity was significantly reduced upon G-CSF treatment in chemosensitive AML samples. Thus, this correlation between pre-clinical ex vivo observation and clinical results might be used to anticipate clinical response to chemotherapy and select optimal therapy.

\section{Results}

In order to study the effect of G-CSF on cell viability, bulk AML blast population was treated with increasing doses of G-CSF. In concordance with previous data [19], no significant differences were observed in cell number 24 and $72 \mathrm{~h}$ after treatment (Fig. 1a, Additional file 1: Figure S1A). Treatment with G-CSF upregulated CXCR4 expression in a dose-dependent fashion (Fig. 1b, Additional file 1: Figure S1B), demonstrating that although G-CSF signaling was activated, no influence over cell
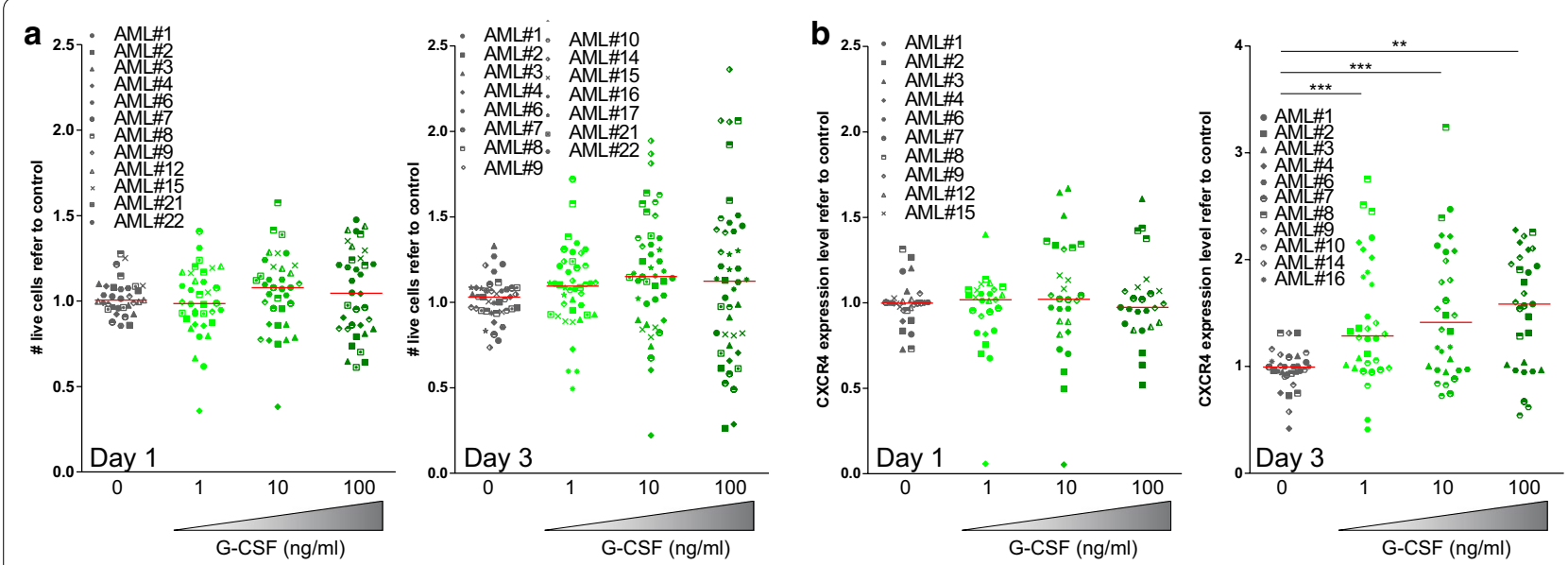

Fig. 1 G-CSF treatment spares AML blasts while it increased surface CXCR4 expression. Primary patient AML cells were cultured in the presence of $0.1,1$ and $10 \mu \mathrm{g} / \mathrm{mL}$ of G-CSF for 24 and $72 \mathrm{~h}$. a Cell viability was measured by live-death discrimination (7-AAD) and volumetric count by flow cytometry. b CXCR4 surface expression was measured by flow cytometry. ${ }^{* *} p<0.01$; ${ }^{* *} p<0.005$ 
viability was observed. In contrast, when bone marrow stroma cells were added to mimic their physiological niche, G-CSF treatment induced a significant reduction in the overall cell viability at $24 \mathrm{~h}$ (Fig. 2a, Additional file 1: Figure S1C). Interestingly, no changes in CXCR4 expression were observed (Fig. 2b, Additional file 1: Figure S1D). The reduction of cell viability observed on AML cells treated with G-CSF was not due to cytotoxicity on bone marrow stroma cells. In fact, stroma cells remained unaffected upon G-CSF treatment in terms of cytotoxicity or morphology (Fig. 2c).

After, the requirement of a direct contact with stroma cells was investigated. Cell viability of the AML blast population remained unaffected when no direct contact with stroma cells was allowed by using a transwell system (Fig. 3a). In addition, CXCR4 expression remained unaffected (Fig. 3b). These findings suggest that the cytotoxic effect of G-CSF on the AML blast population requires not only the presence of bone marrow microenvironment cells, but also a direct contact with stroma cells. However, taking into account the absence of changes in the CXCR4 levels, it is unlikely that the effect is mediated by the CXCR4/CXCL12 axis. In fact, G-CSF exerts its effect also on BM stroma cells.

The ability of G-CSF to induce differentiation and, eventually, sensitization of LSCs to chemotherapy may
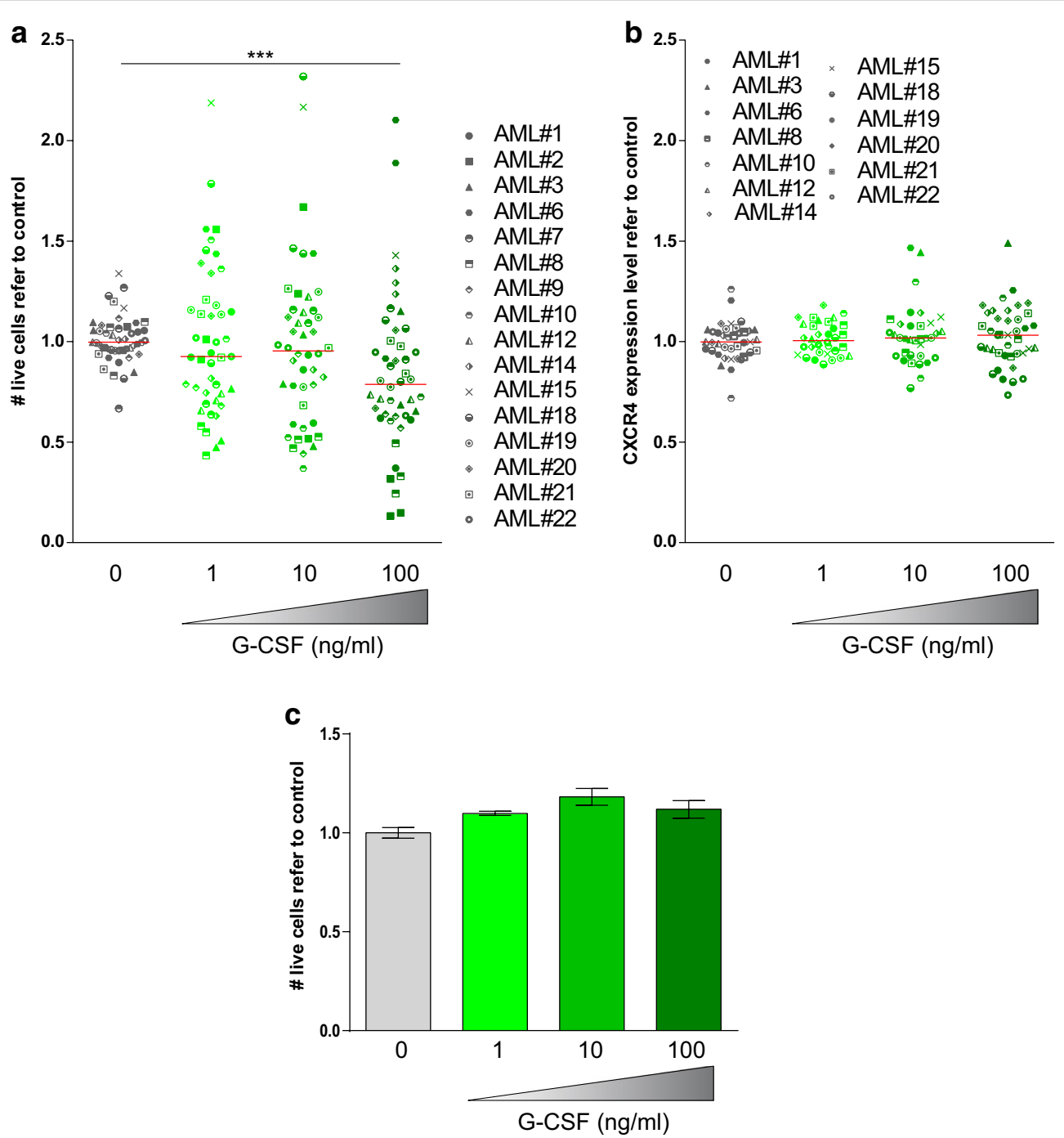

Fig. 2 G-CSF treatment significantly reduced cell viability of AML blasts in the presence of bone marrow stroma, while CXCR4 expression remained unaffected. Primary patient AML cells were co-cultured with HS-5 human bone marrow stromal cell line and treated with G-CSF at increasing concentrations for $24 \mathrm{~h}$. a Cell viability was measured by live-death discrimination (7-AAD) and volumetric count by flow cytometry. b CXCR4 surface expression was measured by flow cytometry. $\mathbf{c ~ H S}-5$ human bone marrow stromal cells were treated with G-CSF at increasing concentrations for $24 \mathrm{~h}$. Cell viability was measured as for $\mathbf{a} .{ }^{* * *} p<0.005$ 

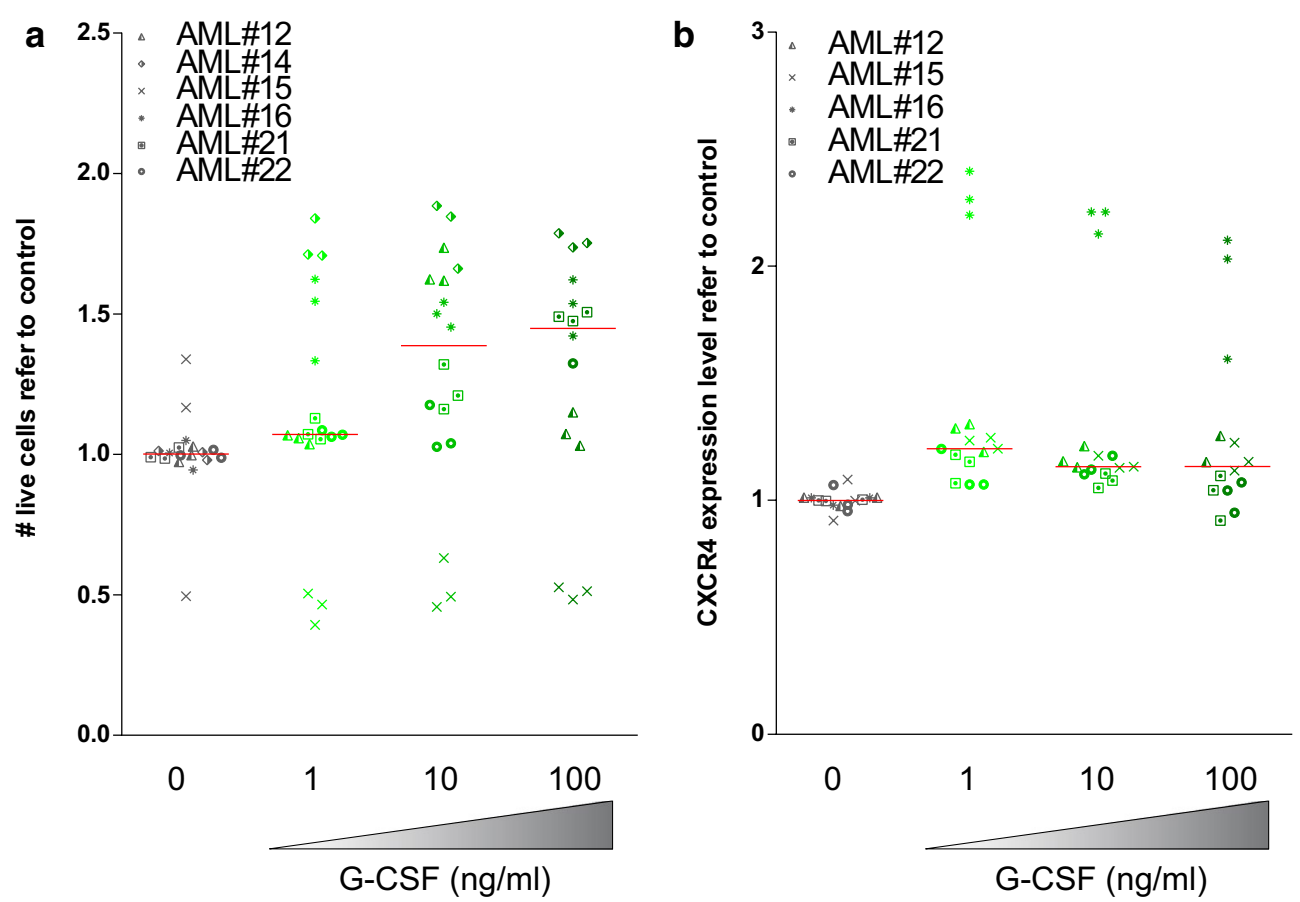

Fig. 3 Cell viability of the AML blast population and CXCR4 expression remained unaffected when no direct contact with stroma cells was allowed. Primary patient AML samples were co-cultured with HS-5 cells in a transwell system and treated with G-CSF at increasing concentrations for $24 \mathrm{~h}$. a Cell viability and $\mathbf{b}$ CXCR4 surface expression were measured by flow cytometry

be relevant in a clinical setting to enhance anti-leukemic effect of current standard treatment [4]. Since a clonogenic capacity assay in a semi-solid media remains the gold standard technique to study the LSC function ex vivo, primary AML samples were treated with G-CSF for $18 \mathrm{~h}$ and a significant reduction of CFU-B colonies was observed in a dose-dependent manner upon treatment with G-CSF (Fig. 4a), suggesting that G-CSF exerts its effect at least partially on LSC function.

The beneficial effect of the concomitant use of G-CSF with induction chemotherapy reported in previous clinical studies was mainly observed in the subset of patients with a cytogenetic intermediate-risk AML [20]. Thus, the response to G-CSF treatment ex vivo of primary AML cells was compared to the observed clinical patient response to the induction chemotherapy regimen. No differences in cell viability were detected both, in the presence or absence of stroma cells, depending on clinical response to induction treatment. In contrast, the clonogenic capacity was markedly reduced in samples from patients who achieved a first complete remission after induction treatment, compared to samples from chemorefractory patients (Fig. 4b).

\section{Discussion}

As a summary, G-CSF reduced the viability of leukemic cells in the presence of stroma cells, highlighting the importance of the microenvironment for the anti-leukemia effect of G-CSF. Interestingly, G-CSF treatment decreased the clonogenic capacity of AML samples. As the clonogenic assay remains the gold standard for assessing LSC functionality, this finding suggests that G-CSF exerts its effect at least partially on LSC. It is in contrast with the lack of effect of G-CSF on leukemic cell viability in the absence of stroma. However, as the frequency of LCS inside the AML bulk population is relatively low, the effect of G-CSF in this leukemic population could be challenging to be measured by flow cytometry. The observed correlation between the degree of reduction of clonogenic capacity of primary AML cells following exposition to G-CSF and clinical response observed in the same patients to induction chemotherapy provide insights to the selective benefit in determined cytogenetic patient populations reported in previous clinical studies. These results are consistent with the previously reported data by the HOVON cooperative group [6], where the unfavorable cytogenetic risk group of patients did not obtain a major clinic benefit from G-CSF priming strategy. The fact that AML samples from primary refractory patients showed a lower reduction in their clonogenic capacity after treatment with G-CSF supports the notion that the priming strategy with this agent should be more efficient in patients with a greater degree of chemosensitivity. 

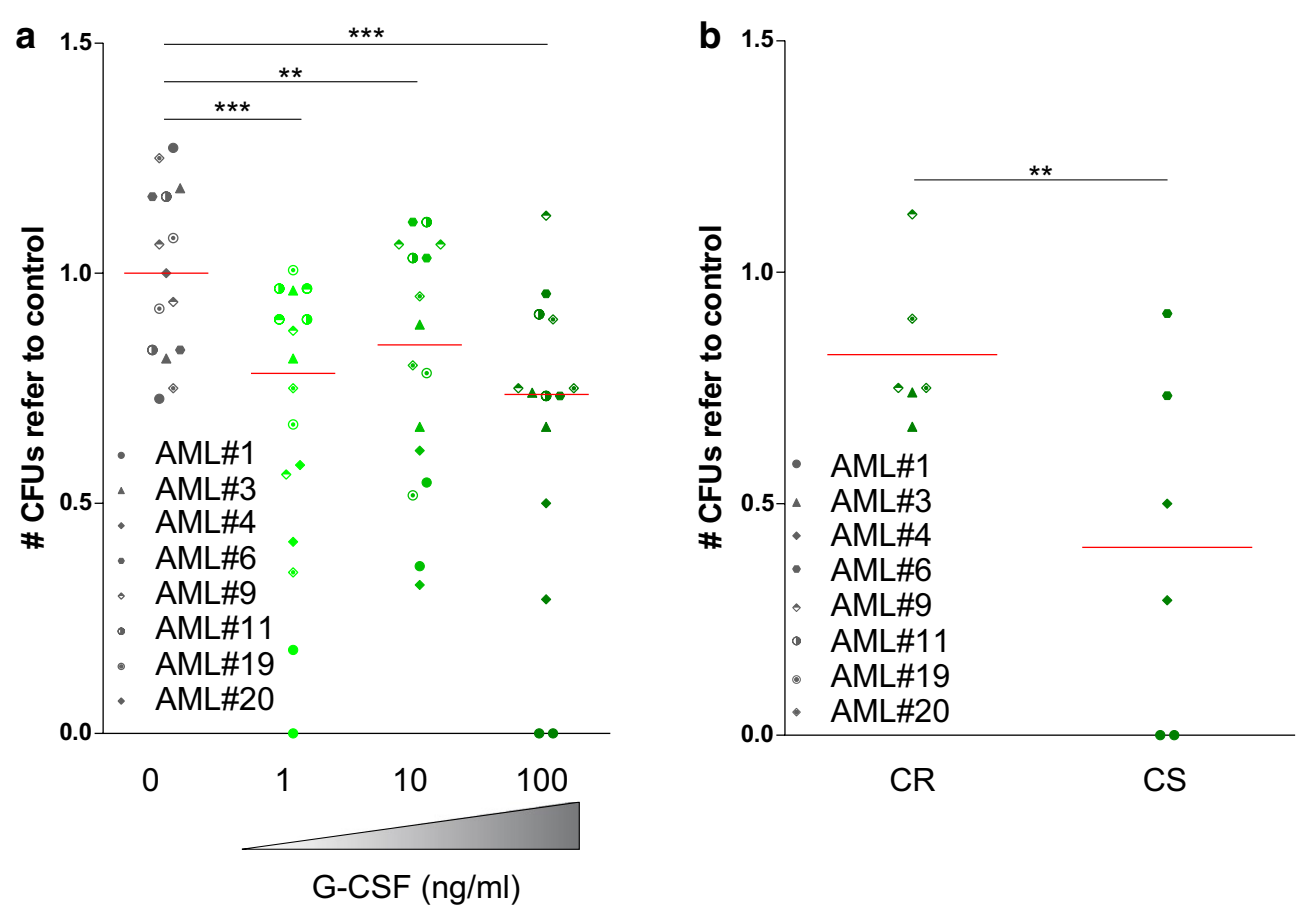

Fig. 4 G-CSF treatment reduced the clonogenic capacity of AML bulk population. Primary patient AML samples were treated with G-CSF as indicated for $18 \mathrm{~h}$. a CFU-B were counted based on morphological criteria. b Relative change in the clonogenic capacity after G-CSF treatment in patients who achieved a complete response after induction treatment (CS) compared to primary chemorefractory patients (CR). Each symbol corresponds to an AML patient. All data was normalized against control. ${ }^{*} p<0.05,{ }^{* *} p<0.01,{ }^{* * *} p<0.001$

Therefore, ex vivo clonogenicity assays could be used to predict clinical response to priming strategies, although further studies aimed to analyze this correlation between experimental and clinical results are required.

\section{Conclusions}

1. Reveals that the cytotoxic effect of G-CSF treatment on AML is stroma-dependent.

2. Demonstrates that the presence of G-CSF reduces the clonogenic capacity of AML blasts, especially in chemosensitive AML cells.

3. Identifies G-CSF as a priming agent in primary chemosensitive patients and supports further studies to explore new strategies of chemotherapy priming in AML patients.

4. Establishes a biological explanation to clinical studies, resolving the discrepancies in the field regarding G-CSF treatment.

\section{Methods}

\section{Patient samples}

Primary AML samples were obtained from patients diagnosed with AML at Hospital Clínic of Barcelona before receiving any treatment. Diagnoses were based on WHO 2008 criteria and their main characteristics are summarized in Table 1. All patients provided written informed consent in accordance with the Declaration of Helsinki, and the study was approved by the Ethics Committee of Hospital Clínic of Barcelona.

\section{Cell viability assay}

Five-hundred cells per $\mathrm{ml}$ were cultured in 96-well plates in complete IMDM medium (PAA). G-CSF (PrepoTech) was added at different concentrations. Coculture experiments with stromal cells were performed seeding $30 \times 10^{3}$ HS- 5 cells together with $1 \times 10^{5}$ AML cells in a 96-well plate. Cell viability was measured by 7-AAD (eBioscience) exclusion and cell count was obtained by volume in a FACSCanto II cytometer (BD). In co-culture experiments, AML cells were discriminated based on their CD45 expression (BD). For CXCR4 determination, cells were stained on the surface with an anti-CXCR4 antibody (clone 12G5, BD) and samples were acquired in a FACSCantoII (BD). Flow cytometry fcs files were analyzed using FlowJo software (TriStar) and statistics were calculated in GraphPad (Prism software). Each experimental point was normalized against the mean value corresponding to the vehicle treated control triplicates. A 2-tailed Mann-Whitney test was performed to determinate statistical significance. 
Table 1 AML patients' characteristics

\begin{tabular}{|c|c|c|c|c|c|c|}
\hline AML sample & Gender & Age (yo) & WHO 2008 category & Karyotype & $\begin{array}{l}\text { NPM1,FLT3-ITD, CEBPA } \\
\text { and DNMT3A mutational } \\
\text { status }\end{array}$ & Chemosensitivity \\
\hline$\# 1$ & M & 28 & $\begin{array}{l}\text { AML NOS, without matura- } \\
\text { tion }\end{array}$ & $46, X Y$ & FLT3 ITD & CS \\
\hline$\# 2$ & M & 40 & AML with mutated CEBPA & $46, X Y$ & CEBPA $^{\text {mut }}$ & \\
\hline \#3 & $\mathrm{F}$ & 34 & $\begin{array}{l}\text { AML with myelodysplasia- } \\
\text { related changes }\end{array}$ & $45, X X,-7$ & FLT3 ITD ${ }^{\text {neg }}, N P M 1^{\text {wt }}$ & $C R$ \\
\hline$\# 4$ & M & 45 & $\begin{array}{l}\text { AML with } \mathrm{t}(6,9)(\mathrm{p} 23 ; \mathrm{q} 34) ; D E K- \\
\text { NUP214 }\end{array}$ & $46, X Y, t(6 ; 9)(p 23 ; q 34)$ & FLT3 ITD & CS \\
\hline \#6 & M & 61 & $\begin{array}{l}\text { AML with t(8;21)(q22;q22); } \\
\text { RUNX1-RUNX1T1 }\end{array}$ & $\begin{array}{l}45, X-Y, t(8 ; 21)(q 22 ; q 22) \\
{[19] / 46, X Y}\end{array}$ & FLT3 ITD ${ }^{\text {neg }}, N P M 1^{\text {wt }}$ & CS \\
\hline \#7 & $\mathrm{F}$ & 58 & $\begin{array}{l}\text { AML with myelodysplasia- } \\
\text { related changes }\end{array}$ & $\begin{array}{l}\text { 46, XX, del(5)(q23q33), t(8;9) } \\
\quad(\text { p11;q34) }\end{array}$ & FLT3 ITD neg, NPM $1^{\text {wt }}$ & \\
\hline$\# 8$ & M & 24 & $\begin{array}{l}\text { AML with myelodysplasia- } \\
\text { related changes }\end{array}$ & $46, X Y$ & FLT3 ITD ${ }^{\text {neg }}, N P M 1$ wt & \\
\hline \#9 & M & 49 & $\begin{array}{l}\text { AML with myelodysplasia- } \\
\text { related changes }\end{array}$ & Complex karyotype & FLT3 ITD ${ }^{\text {neg }}$, NPM $^{\text {wt }}$ & \\
\hline$\# 10$ & $\mathrm{~F}$ & 66 & $\begin{array}{l}\text { AML with myelodysplasia- } \\
\text { related changes }\end{array}$ & $46, X X$, del(11)(q22q23) & FLT3 ITD & \\
\hline \#11 & M & 22 & $\begin{array}{l}\text { AML with } \mathrm{t}(8 ; 21)(\mathrm{q} 22 ; \mathrm{q} 22) ; \\
\text { RUNX1-RUNX1T1 }\end{array}$ & $\begin{array}{l}45, X_{1}-Y, t(8 ; 21)(q 22 ; q 22) / 46 \\
\quad X Y\end{array}$ & FLT3 ITD & CS \\
\hline$\# 12$ & $\mathrm{~F}$ & 22 & $\begin{array}{l}\text { AML with inv(16) } \\
\text { (p13.1q22);CBFB-MYH11 }\end{array}$ & $46, X X, \operatorname{inv}(16)(p 13 q 22) / 46, X X$ & FLT3 ITD ${ }^{\text {neg }}$, NPM $^{\text {wt }}$ & \\
\hline$\# 13$ & M & 37 & AML with mutated NPM1 & $46, X Y$ & NPM1 ${ }^{\text {mut }}$, DNMT3A ${ }^{\text {mut }}$ & \\
\hline$\# 14$ & M & 42 & AML with mutated NPM1 & $46, X Y$ & NPM1 $1_{\text {mut }}$, FLT3 ITD & \\
\hline$\# 15$ & $\mathrm{~F}$ & 60 & $\begin{array}{l}\text { AML with myelodysplasia- } \\
\text { related changes }\end{array}$ & $48, X X,+8,+21$ & FLT3 ITD ${ }^{\text {neg }}, N P M 1^{\text {wt }}$ & \\
\hline \#16 & $\mathrm{F}$ & 62 & AML NOS, with maturation & $46, X X$ & FLT3 ITD ${ }^{\text {neg }}$, NPM1 ${ }^{\text {wt }}$ & \\
\hline$\# 17$ & $\mathrm{~F}$ & 60 & $\begin{array}{l}\text { AML with myelodysplasia- } \\
\text { related changes }\end{array}$ & Complex karyotype & FLT3 ITD ${ }^{\text {neg }}$, NPM $1^{\text {wt }}$ & \\
\hline$\# 18$ & $\mathrm{~F}$ & 55 & $\begin{array}{l}\text { AML with inv(16) } \\
\text { (p13.1q22);CBFB-MYH11 }\end{array}$ & $46, X X, \operatorname{inv}(16)(p 13 q 22) / 46, X X$ & FLT3 ITD ${ }^{\text {neg }}, N P M 1^{\text {wt }}$ & \\
\hline \#19 & M & 63 & $\begin{array}{l}\text { AML with myelodysplasia- } \\
\text { related changes }\end{array}$ & $46, X Y$ & FLT3 ITD & $C R$ \\
\hline \#20 & M & 61 & AML with mutated NPM1 & $46, X Y$ & NPM1 ${ }^{\text {mut }}$, DNMT3A ${ }^{\text {mut }}$ & $C R$ \\
\hline \#21 & $\mathrm{F}$ & 51 & $\begin{array}{l}\text { AML NOS, acute monoblastic } \\
\text { leukemia }\end{array}$ & Not available & NPM1 ${ }^{\text {mut }}$, FLT3 ITD neg & \\
\hline \#22 & $\mathrm{F}$ & 36 & AML with mutated NPM1 & $46, X X$ & NPM1 ${ }^{\text {mut }}$, FLT3 ITD ${ }^{\text {neg }}$ & \\
\hline
\end{tabular}

$M$ male, F female, yo years old, FLT3-ITD FLT3 internal tandem duplication, CEBPA ${ }^{\text {mut }}$ biallelic CEBPA mutation, FLT3 ITD ${ }^{\text {neg }}$ absence of FLT3-ITD, NPM1wt wild-type NPM1, $N P M 1^{\text {mut }}$ mutated NPM1, Wt wildtype

\section{Transwell assay}

Membranes with $1 \mu \mathrm{m}$ pore size (Falcon) were used in a 24-wells format. A total of 100,000 HS-5 cells were added to the lower compartment. 300,000 primary AML patient samples were added to the upper compartment. Both compartments were filled with complete media as described above. Cells were incubated $24 \mathrm{~h}$ and analyzed as for viability assays.

\section{CFU assay}

AML primary samples were treated for $18 \mathrm{~h}$ with G-CSF (PrepoTech) at different concentrations in complete IMDM medium and cultured in MethoCult H4034
(StemCell Technologies) for 14 days. Colonies were counted based on cellularity and morphology criteria.

\section{Additional file}

Additional file 1: Figure S1. G-CSF treatment significantly reduced cell viability of AML blasts in the presence of bone marrow stroma. Primary patient AML cells were cultured in the presence of $0.1,1$ and $10 \mu \mathrm{g} / \mathrm{mL}$ of G-CSF for 24 and 72 h. (A) Cell viability was measured by live-death discrimination (7-AAD) and volumetric count by flow cytometry. (B) CXCR4 surface expression was measured by flow cytometry. The same primary patient AML sample set was co-cultured with HS-5 human bone marrow stromal cell line and treated with G-CSF at increasing concentrations for $24 \mathrm{~h}$. (C) Cell viability was measured by live-death discrimination (7-AAD) and volumetric count by flow cytometry. (D) CXCR4 surface expression was measured by flow cytometry. 


\section{Authors' contributions}

$\mathrm{MN}$, designed the research, performed experiments, analyzed data and wrote the paper; MCLC, performed experiments, analyzed data; AE, performed experiments, analyzed data; JMCM: performed experiments, analyzed data; $\mathrm{MP}$, analyzed data; $\mathrm{MDB}$, analyzed data; XC, analyzed data; MR, analyzed data; $\mathrm{DC}$, analyzed data; JE, designed the research, analyzed data; RMR, designed the research, performed experiments, analyzed results and wrote the paper. All authors read and approved the final manuscript.

\section{Author details}

${ }^{1}$ Josep Carreras Leukaemia Research Institute, Campus Clínic-University of Barcelona, Rosselló 149-153, 08036 Barcelona, Spain. ${ }^{2}$ Department of Hematology, Hospital Clínic, Barcelona, Spain. ${ }^{3}$ Institut d'Investigacions Biomèdiques August Pi i Sunyer, Barcelona, Spain. ${ }^{4}$ Hematopathology Unit, Hospital Clínic, Barcelona, Spain. ${ }^{5}$ Fundació Clínic per a la Recerca Biomèdica, Barcelona, Spain.

\section{Acknowledgements}

MN received a Premi Fi de Residència Emili Letang of Hospital Clínic de Barcelona and RMR is supported by Ramón y Cajal program/Ministry of Economy (RYC-2011-07998). This work was in part supported by Fundació Internacional Josep Carreras and I'Obra Social "La Caixa"-Fundació Bancària "La Caixa" (RMR), Fondo de Investigaciones Sanitarias PI08/0158 (JE) and PI13/0999 (JE); and RD06/0020/0004 (JE) and RD12/0036/0010 (RMR and JE).

\section{Competing interests}

The authors declare no competing financial interests.

Received: 16 October 2015 Accepted: 10 December 2015

Published online: 21 December 2015

\section{References}

1. Bonnet D, Dick JE. Human acute myeloid leukemia is organized as a hierarchy that originates from a primitive hematopoietic cell. Nat Med. 1997;3(7):730-7.

2. Ishikawa F, Yoshida S, Saito Y, Hijikata A, Kitamura H, Tanaka S, Nakamura $\mathrm{R}$, Tanaka T, Tomiyama H, Saito N, et al. Chemotherapy-resistant human AML stem cells home to and engraft within the bone-marrow endosteal region. Nat Biotechnol. 2007;25(11):1315-21.

3. Sison EA, Brown P. The bone marrow microenvironment and leukemia: biology and therapeutic targeting. Expert Rev Hematol. 2011;4(3):271-83.

4. Beekman R, Touw IP. G-CSF and its receptor in myeloid malignancy. Blood. 2010;115(25):5131-6.

5. Broxmeyer HE, Kohli L, Kim CH, Lee Y, Mantel C, Cooper S, Hangoc G, Shaheen M, Li X, Clapp DW. Stromal cell-derived factor-1/CXCL12 directly enhances survival/antiapoptosis of myeloid progenitor cells through CXCR4 and G(alpha)i proteins and enhances engraftment of competitive, repopulating stem cells. J Leukoc Biol. 2003;73(5):630-8.

6. Lowenberg B, van Putten W, Theobald M, Gmur J, Verdonck L, Sonneveld P, Fey M, Schouten $H$, de Greef G, Ferrant A, et al. Effect of priming with granulocyte colony-stimulating factor on the outcome of chemotherapy for acute myeloid leukemia. N Engl J Med. 2003;349(8):743-52.

7. Pabst T, Vellenga E, van Putten W, Schouten HC, Graux C, Vekemans MC, Biemond B, Sonneveld P, Passweg J, Verdonck L, et al. Favorable effect of priming with granulocyte colony-stimulating factor in remission induction of acute myeloid leukemia restricted to dose escalation of cytarabine. Blood. 2012;119(23):5367-73.

8. Heil G, Hoelzer D, Sanz MA, Lechner K, Liu Yin JA, Papa G, Noens L, Szer J, Ganser A, O'Brien C, et al. A randomized, double-blind, placebocontrolled, phase III study of filgrastim in remission induction and consolidation therapy for adults with de novo acute myeloid leukemia. The International Acute Myeloid Leukemia Study Group. Blood. 1997;90(12):4710-8.
9. Dombret H, Chastang C, Fenaux P, Reiffers J, Bordessoule D, Bouabdallah R, Mandelli F, Ferrant A, Auzanneau G, Tilly H, et al. A controlled study of recombinant human granulocyte colony-stimulating factor in elderly patients after treatment for acute myelogenous leukemia. AML Cooperative Study Group. N Engl J Med. 1995;332(25):1678-83.

10. Liongue C, Wright C, Russell AP, Ward AC. Granulocyte colony-stimulating factor receptor: Stimulating granulopoiesis and much more. Int J Biochem Cell Biol. 2009;41(12):2372-5.

11. Avalos BR. The granulocyte colony-stimulating factor receptor and its role in disorders of granulopoiesis. Leukemia Lymphoma. 1998;28(3-4):265-73.

12. Touw IP, van de Geijn GJ. Granulocyte colony-stimulating factor and its receptor in normal myeloid cell development, leukemia and related blood cell disorders. Front Biosci. 2007;12:800-15.

13. Souza LM, Boone TC, Gabrilove J, Lai PH, Zsebo KM, Murdock DC, Chazin VR, Bruszewski J, Lu H, Chen KK, et al. Recombinant human granulocyte colony-stimulating factor: effects on normal and leukemic myeloid cells. Science. 1986;232(4746):61-5.

14. DeLaLuzSierra M, Gasperini P, McCormick PJ, Zhu J, Tosato G. Transcription factor Gfi-1 induced by G-CSF is a negative regulator of CXCR4 in myeloid cells. Blood. 2007;110(7):2276-85.

15. Ohno R, Naoe T, Kanamaru A, Yoshida M, Hiraoka A, Kobayashi T, Ueda T, Minami S, Morishima Y, Saito Y, et al. A double-blind controlled study of granulocyte colony-stimulating factor started two days before induction chemotherapy in refractory acute myeloid leukemia, Kohseisho Leukemia Study Group. Blood. 1994;83(8):2086-92.

16. Estey EH, Thall PF, Pierce S, Cortes J, Beran M, Kantarjian H, Keating MJ, Andreeff M, Freireich E. Randomized phase II study of fludarabine + cytosine arabinoside + idarubicin \pm all-trans retinoic acid \pm granulocyte colony-stimulating factor in poor prognosis newly diagnosed acute myeloid leukemia and myelodysplastic syndrome. Blood. 1999;93(8):2478-84.

17. Ossenkoppele GJ, van der Holt B, Verhoef GE, Daenen SM, Verdonck LF, Sonneveld P, Wijermans PW, van der Lelie J, van Putten WL, Lowenberg B. A randomized study of granulocyte colony-stimulating factor applied during and after chemotherapy in patients with poor risk myelodysplastic syndromes: a report from the HOVON Cooperative Group. Dutch-Belgian Hemato-Oncology Cooperative Group. Leukemia. 1999;13(8):1207-13.

18. Amadori S, Suciu S, Jehn U, Stasi R, Thomas X, Marie JP, Muus P, Lefrere $F$, Berneman Z, Fillet $G$, et al. Use of glycosylated recombinant human G-CSF (lenograstim) during and/or after induction chemotherapy in patients 61 years of age and older with acute myeloid leukemia: final results of AML-13, a randomized phase-3 study. Blood. 2005;106(1):27-34.

19. Begley CG, Metcalf D, Nicola NA. Primary human myeloid leukemia cells: comparative responsiveness to proliferative stimulation by GMCSF or G-CSF and membrane expression of CSF receptors. Leukemia. 1987;1(1):1-8.

20. Wheatley K, Burnett AK, Goldstone AH, Gray RG, Hann IM, Harrison CJ, Rees JK, Stevens RF, Walker H. A simple, robust, validated and highly predictive index for the determination of risk-directed therapy in acute myeloid leukaemia derived from the MRC AML 10 trial. United Kingdom Medical Research Council's Adult and Childhood Leukaemia Working Parties. Br J Haematol. 1999;107(1):69-79.

\section{Submit your next manuscript to BioMed Central and we will help you at every step:}

- We accept pre-submission inquiries

- Our selector tool helps you to find the most relevant journal

- We provide round the clock customer support

- Convenient online submission

- Thorough peer review

- Inclusion in PubMed and all major indexing services

- Maximum visibility for your research

Submit your manuscript at www.biomedcentral.com/submit

() Biomed Central 